\title{
The short- and long-term effects of changes of vegetation structure on isopod (Oniscidea) diversity and composition in Mátra Mountains
}

\author{
Diána VONA-TÚRI, ${ }^{1}$ Tünde SZMATONA-TÚRI ${ }^{2}$ \\ ${ }^{1}$ Eötvös József Reformated Education Centre, 29 Dobó Street, Heves 3360, Hungary \\ e-mail: turidiana79@gmail.com ORCID: 0000-0003-3910-8898 \\ ${ }^{2}$ FM ASzK - Forestry, Agricultural and Game Management Training School and \\ Student Hostel of Mátra, 11 Erdész street, Mátrafüred 3232, Hungary \\ e-mail: turitunde79@gmail.com ORCID: 0000-0002-8314-3183
}

Manuscript received October 2017

\begin{abstract}
The aim of the present study was to examine the short- and long-term effects of changes in vegetation structure caused by shrub removal and mowing on isopod diversity and composition in Natura 2000 habitats of Mátra Landscape Protection Area. Species richness and isopod diversity increased in the short term as a result of annual changes in vegetation; however, the values of both indices were reduced in the long term. The changes in vegetation structure on a regional scale led to a reduced isopod diversity in the short and long term. The changes in vegetation structure caused alterations in community structure in the long term. We conclude that changes of vegetation structure have a negative effect on species richness and the diversity of isopod communities in the long term.
\end{abstract}

Keywords: Hungary, mowing, shrub removal, grasslands

\section{Introduction}

The formation of open habitats is a long-term process caused by deforestation; later on, mowing and grazing contribute to the maintenance of meadows. Changing or elimination of traditional management contributed to the re-formation of shrubs and forests [1], but this succession process can be reversed by treatments, namely shrub removal and mowing [2, 3]. Since 2000, the Bükk National Park Directorate has conducted a soil-zoological monitoring for the KEOP project (Restoration and treatment of lawns, meadows, and woody pastures) in the Mátra Mountains in 
order to reconstruct open habitats or maintain its current form. The protection of grasslands is important to the fauna as well because the arthropod species significant from a nature conservation point of view are attached to lawn plant species [4]. Grassland managements change the structure and composition of vegetation $[5,6]$, which affects the micro-climatic conditions of habitats, such as temperature, soil humidity, nutrient source, and lighting conditions. For example, mowing can create changes below the ground that have an effect on plant growth [7], such as decreasing of nitrogen mineralization in the soil [8]. Similarly, Turgeon [9] reported that mowing is detrimental from a botanical standpoint. Opposite to this, Ilmarinen and Mikola [10] concluded that mowing increased the areal cover of legumes, and it has less effect on the areal cover of individual woody species compared to the total cover of the woody plant group that is reduced. High floral diversity positively affects the diversity of flower-visiting insects [11] and therefore predatory arthropods such as spiders [12, 13, 14, 15] and beetles [16]. Opposite to this, some representatives of other trophic levels are affected by other conditions and the connection with the number of microhabitats. Terrestrial isopods are ground-dwelling crustaceans, members of the decomposer macrofauna $[17,18]$. Isopods play an important role in decomposition processes through the fragmentation and mineralization of dead organic matter [19]. The food of isopods consists of fungi, bacteria, decayed wood, and leaf litter, as their weathering with conditioning by microorganisms improves their palatability for the isopods [20]. Isopods are considered the most successful crustacean colonizers of land habitats with wide ecological tolerance [21]. They were found in most mesic, xeric, and hydric habitats $[22,21]$ worldwide, with the exception of the poles and very high elevations [23]. Moreover, they tolerate high levels of copper and ammonia [24, $25,26]$. However, their dispersion ability is limited because the temperature and humidity of environment strongly influence their mortality and natality [27].

The main objectives of this study were to investigate the effects of changes in vegetation structure on isopod diversity. Firstly, we studied how the annual changes in vegetation structure impact isopod diversity in the short and long term. We examined changes in isopod diversity in relation to a sudden change of vegetation structure caused by shrub removal in the short term (between the years 2012 and 2013). Also in these created open habitats, we studied how isopod diversity changes in the long term (between the years 2012 and 2014). We hypothesized that changes in vegetation structure have a negative effect on isopod diversity in the short term. Moreover, we expected the further decreasing of diversity in the course of the previous year. Secondly, we explored how the changes in vegetation structure affect isopod diversity and composition on a regional scale. We analysed the differences between habitats (control shrubs, removal shrubs, and hay meadow) to examine the effect of vegetation structure changes in the short term (removal shrubs) and long term (hay meadow). We 
hypothesized that the highest isopod diversity will be in control shrubs, while the lowest will be in hay meadows because of defoliation.

\section{Materials and methods}

\section{A. Sampling areas and methods}

We sampled terrestrial isopods in three localities (Sár Hill Nature Reserve, Gyöngyössolymos, and Fallóskut) in the Mátra Mountains as shown in Fig. 1. Three sampling sites were selected in all localities, representing control shrubs (no removal), removal shrubs (cut once), and hay meadows (mown once a year), as shown in Table 1.

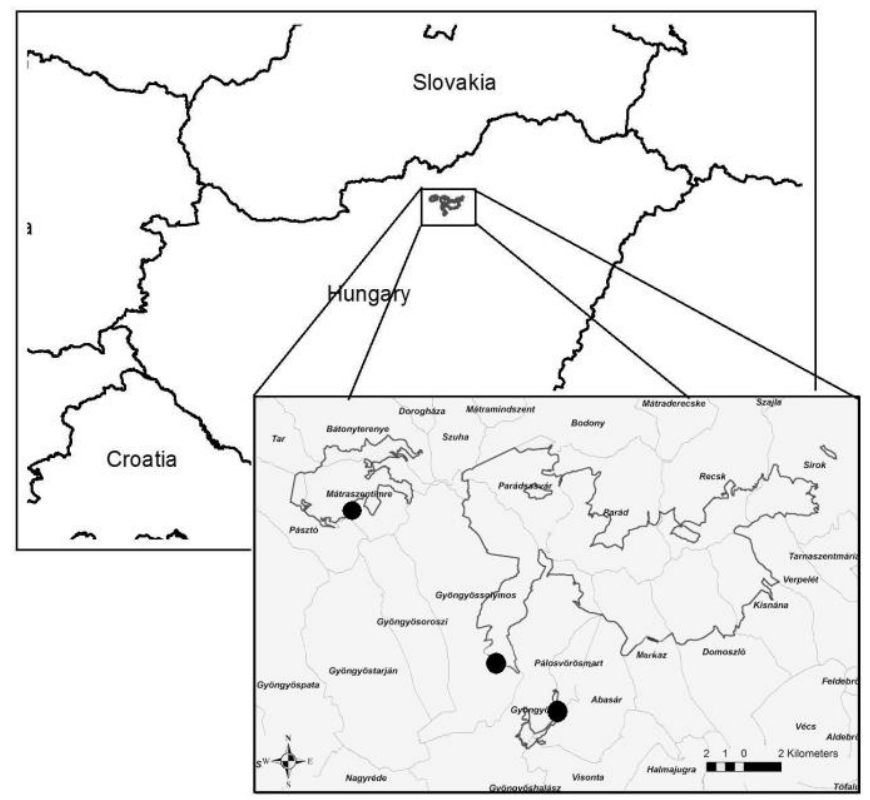

Figure 1. Map of sampling sites in Hungary

Double-glass pitfall traps filled with $65 \%$ ethylene glycol were established on the sampling sites between 2012 and 2014. Five traps were set at a distance of 4-5 $\mathrm{m}$ along a transect on every sampling site. Traps were deployed twice (May-July, September-November) over a six-week period each year. Grassland management was undertaken in those habitats with advanced succession. Shrub removal done manually was the first phase of the treatment process and occurred at the end of 2012, following sampling. Additional treatments during the following year (20132014) did not take place, but possibly following stem mashing and finally mowing 
would be necessary. The hay meadows were mown with a mowing machine in all years, in summer or autumn, depending on the weather conditions. The treatments were carried out in a rotational manner, reserving a small portion of intact (unmown) habitat each year. In order to analyse the effect of annual changes in vegetation, we compared data of different years: in the short term between 2012 and 2013 and in the long term between 2012 and 2014. To assess the effect of changes in vegetation on a regional scale, we considered data of different sampling sites: in the short term: between control shrubs and removal shrubs, in the long term: between control shrubs and hay meadows.

Table 1. Characteristics of the sampling sites

\begin{tabular}{|c|c|c|c|c|c|}
\hline Sites & $\begin{array}{l}\text { Altitude } \\
(\mathrm{m})\end{array}$ & Land usage & $\begin{array}{l}\text { Vegetation } \\
\text { sturcture }\end{array}$ & $\begin{array}{l}\text { Size } \\
\text { (ha) }\end{array}$ & Vegetation \\
\hline \multirow{3}{*}{$\begin{array}{l}\text { Gyöngyös- } \\
\text { solymos }\end{array}$} & \multirow{3}{*}{300} & \multirow{3}{*}{$\begin{array}{l}\text { Sheep } \\
\text { pastured }\end{array}$} & Hay meadow & 5 & $\begin{array}{l}\text { Campanulo-Stipetum } \\
\text { tirsae }\end{array}$ \\
\hline & & & Control shrub & 1 & $\begin{array}{l}\text { Pruno spinosae- } \\
\text { Crataegetum } \\
\text { with forest steppe items } \\
\text { e.g. Acer tataricum }\end{array}$ \\
\hline & & & $\begin{array}{l}\text { Removed } \\
\text { shrub }\end{array}$ & 1 & $\begin{array}{l}\text { Campanulo-Stipetum } \\
\text { tirsae }\end{array}$ \\
\hline \multirow{3}{*}{ Sár Hill } & \multirow{3}{*}{350} & \multirow{3}{*}{ Vineyard } & Hay meadow & 3 & $\begin{array}{l}\text { Campanulo-Stipetum } \\
\text { tirsae }\end{array}$ \\
\hline & & & Control shrub & 1 & $\begin{array}{l}\text { Pruno spinosae- } \\
\text { Crataegetum }\end{array}$ \\
\hline & & & $\begin{array}{l}\text { Removed } \\
\text { shrub }\end{array}$ & 1 & $\begin{array}{l}\text { Pulsatillo montanae- } \\
\text { Festucetum rupicolae }\end{array}$ \\
\hline \multirow{3}{*}{ Fallóskút } & \multirow{3}{*}{700} & \multirow{3}{*}{$\begin{array}{l}\text { Hay } \\
\text { meadow and } \\
\text { pastured }\end{array}$} & Hay meadow & 1 & $\begin{array}{l}\text { Anthyllido-Festucetum } \\
\text { rubrae }\end{array}$ \\
\hline & & & Control shrub & 2 & $\begin{array}{l}\text { Pruno spinosae- } \\
\text { Crataegetum with } \\
\text { Quercus ceris, Carpinus } \\
\text { betulus }\end{array}$ \\
\hline & & & $\begin{array}{l}\text { Removed } \\
\text { shrub }\end{array}$ & 1 & $\begin{array}{l}\text { Pastinaco- } \\
\text { Arrhenatheretum }\end{array}$ \\
\hline
\end{tabular}

\section{B. Statistical analyses}

We used the PAST Paleontological Statistic suite for data analysis [28]. The characterization of isopod communities was based on relative abundance (Ar) and frequency $(\mathrm{F})$. Besides species richness $(\mathrm{S})$ and the number of individuals $(\mathrm{N})$, we computed Shannon-Wiener diversity (H), Simpson's diversity (1-D), and evenness (E) (Pielou's index). The Shannon-Wiener index is more sensitive to the frequency of rare species [29, 30, 31]. Species with the highest abundance have the greatest 
influence on the Simpson's index [29, 30, 31]. The Pielou evenness index expresses the evenness of the distribution of the species and is sensitive to the change of rare species $[30,31]$. The value of species turnover between habitat types was evaluated with Wilson \& Shmida's Beta diversity index $(\beta T)$. The level of complementarity of habitats within the study area was characterized with Whittaker's $\beta$-diversity index ( $\beta \mathrm{W}$ ) [31]. Whittaker's $\beta$-diversity index depicts the relationship between alpha diversity and total number of species. We applied the Jaccard similarity index for pairwise comparison of similarities of habitats based on species composition. The Jaccard similarity index calculates the similarity based on the absence and presence of the species [32]. For better demonstration, community separation was represented with Detrended Correspondence Analysis. The Friedman test was applied to compare the ecological indices using XLSTAT 14.0.7188.5002 version software (https://www.xlstat.com). We used the keys of Hopkin [33], Schmidt [34], and Farkas and Vilisics [35] for identification of isopod specimens. Species' names were applied according to Schmalfuss [36].

\section{Results}

We collected a total of 5 isopod species composed of 675 specimens at 9 sampling sites, as shown in Table 2.

Table 2. Distribution of isopod species in sampling sites

\begin{tabular}{|c|c|c|c|c|c|c|c|}
\hline \multirow[t]{2}{*}{ Abbr } & \multirow[t]{2}{*}{ Species } & \multicolumn{2}{|c|}{$\begin{array}{c}\text { Control } \\
\text { shrubs }\end{array}$} & \multicolumn{2}{|c|}{$\begin{array}{c}\text { Removed } \\
\text { shrubs }\end{array}$} & \multicolumn{2}{|c|}{$\begin{array}{c}\text { Hay } \\
\text { meadows }\end{array}$} \\
\hline & & $\mathrm{Ar} \%$ & F\% & $\mathrm{Ar} \%$ & F\% & $\mathrm{Ar} \%$ & F\% \\
\hline & \multicolumn{7}{|l|}{ Trachelipodidae } \\
\hline P. coll & $\begin{array}{l}\text { Porcellium collicola } \\
\text { (Verhoef, 1907) }\end{array}$ & 5.2 & 100 & 3.8 & 33 & 2.2 & 66 \\
\hline T. rath & $\begin{array}{l}\text { Trachelipus rathkii } \\
\text { (Brandt, 1833) }\end{array}$ & 14.8 & 66 & 84.6 & 66 & 95.5 & 100 \\
\hline \multirow[t]{2}{*}{ T. ratz } & $\begin{array}{l}\text { Trachelipus ratzeburgii } \\
\text { (Brandt, 1833) }\end{array}$ & 0.39 & - & 3.8 & 33 & - & - \\
\hline & \multicolumn{7}{|l|}{ Agnaridae } \\
\hline \multirow[t]{2}{*}{ O. pla } & $\begin{array}{l}\text { Orthometopon planum } \\
\text { (Budde-Lund, 1885) }\end{array}$ & 3.39 & 66 & 3.8 & 33 & 2.2 & 66 \\
\hline & \multicolumn{7}{|l|}{ Armadillidiidae } \\
\hline A. vul & $\begin{array}{l}\text { Armadillidium vulgare } \\
\text { (Latreille, 1804) }\end{array}$ & 76.1 & 33 & 3.8 & 33 & - & 33 \\
\hline
\end{tabular}

We did not find significant differences between the ecological parameters of communities relative to annual changes in vegetation structure, as shown in Table 
3. We observed the highest species richness and diversity in the year following shrub removal; thus, changes of vegetation structure caused the increasing of isopod diversity and species richness in the short term. The values of both indices were reduced last year, as shown in Table 4.

Table 3. Differences between ecological parameters relative to changes in vegetation structure on annual and regional scales by the Friedman test

\begin{tabular}{|c|c|c|c|c|}
\hline \multirow{4}{*}{$\begin{array}{c}\text { Change in vegetation } \\
\text { structure }\end{array}$} & \multicolumn{2}{|c|}{ Annual } & \multicolumn{2}{|c|}{ Regional } \\
\hline & \multirow{2}{*}{ short term } & \multirow[t]{2}{*}{ long term } & short term & long term \\
\hline & & & \multicolumn{2}{|c|}{ Between control shrubs and } \\
\hline & $2012-2013$ & 2012-2014 & $\begin{array}{c}\text { removal } \\
\text { shrubs }\end{array}$ & $\begin{array}{c}\text { hay } \\
\text { meadows }\end{array}$ \\
\hline $\mathrm{Q}$ (Observed value) & 1 & 0 & 4 & 4 \\
\hline $\mathrm{Q}$ (Critical value) & 3.841 & 3.841 & 3.841 & 3.841 \\
\hline DF & 1 & 1 & 1 & 1 \\
\hline$p$-value & 0.317 & 1.000 & 0.046 & 0.046 \\
\hline alpha & 0.05 & 0.05 & 0.05 & 0.05 \\
\hline
\end{tabular}

Table 4. Annual changes in the number of isopod species (S), number of individuals (N), Shannon-Wiener diversity (H), Simpson's diversity (1-D), and evenness (E)

\begin{tabular}{|c|c|c|c|}
\hline Indices & 2012 & 2013 & 2014 \\
\hline $\mathrm{S}$ & 3 & 5 & 1 \\
\hline $\mathrm{N}$ & 12 & 11 & 15 \\
\hline $\mathrm{H}$ & 0.9184 & 1.16 & 0 \\
\hline $1-\mathrm{D}$ & $0 ., 5694$ & 0.562 & 0 \\
\hline
\end{tabular}

On a regional scale, the ecological parameters of communities have differed significantly between habitats, as shown in Table 3. The lowest species richness and isopod diversity were observed in hay meadows, while we recorded the highest isopod diversity in control shrubs, as shown in Table 5. A negative correlation was observed between isopod diversity and the number of individuals in the short and long term. We did not find correlations between isopod diversity and number of individuals among the three habitats, as shown in Fig. 2.

Table 5. Number of isopod species (S), number of individuals (N), Shannon-Wiener diversity (H), Simpson's diversity (1-D), and evenness (E) at a regional scale

\begin{tabular}{|c|c|c|c|}
\hline Indices & Control shrubs & Removed shrubs & Hay meadows \\
\hline S & 5 & 5 & 3 \\
\hline N & 511 & 26 & 90 \\
\hline H & 0.7814 & 0.6426 & 0.2126 \\
\hline 1-D & 0.3945 & 0.2781 & 0.08593 \\
\hline E & 0.4369 & 0.3803 & 0.4123 \\
\hline
\end{tabular}



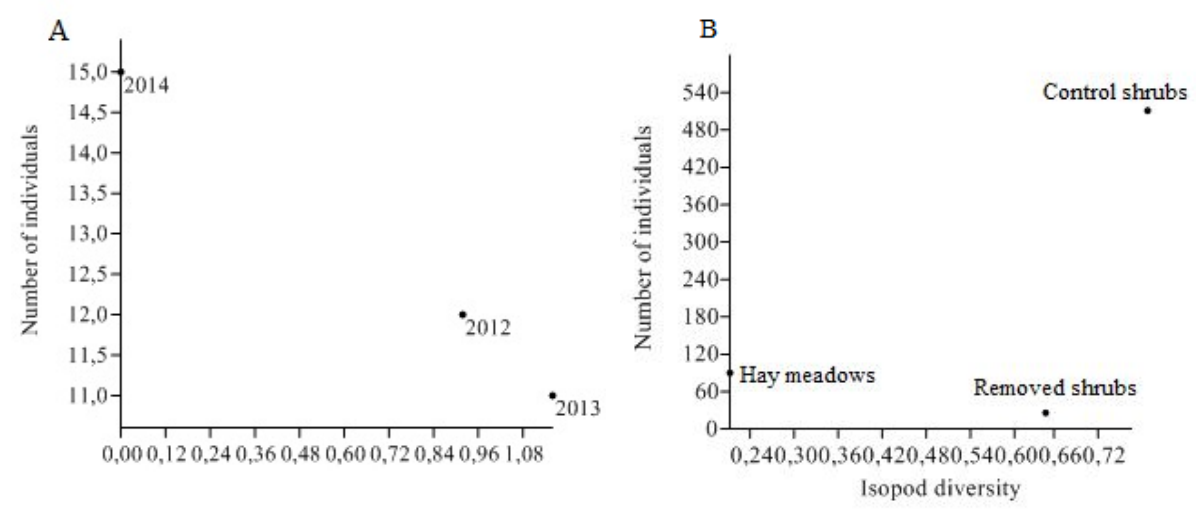

Figure 2. Correlation between isopod diversity and number of individuals in the period of 2012-2014 and in the different habitats (removal shrubs, control shrubs, hay meadows)

We found an increase in the species turnover between years in removal shrubs (2012-2013: 0.25, 2012-2014: 0.5). Between control shrubs and removal shrubs, the values of Wilson \& Shmida's Beta diversity index is zero. Species turnover was the same in the hay meadows from removal shrubs (0.25) and control shrubs $(0,25)$. There was a decrease in the Jaccard similarity index between the assemblages of removal shrubs (2012-2013: 0.6, 2012-2014: 0.33). Between control shrubs and removal shrubs, the values of Jaccard similarity index is 1 . We found the same differences in hay meadows from removal shrubs (0.6) and control shrubs (0.6). The complementarity of isopods was especially low between these habitats. Whittaker's $\beta$ species diversity was 0.15 .

Examining the effect of annual changes in vegetation structure on isopods, we observed a low abundance in all years. In the first year, we found a generalist ( $T$. rathkii) and two forest specialist ( $T$. ratzeburgii, $O$. planum) species. The sudden change of vegetation structure resulted in the appearance of more generalist species ( $P$. collicola, A. vulgare) in the second year. In the third year, only the T. rathkii tolerated the changed conditions in the long term, and its relative abundance increased continually as shown in Table 2. Examining the effect of changes in vegetation structure on a regional scale, we have not found significant differences between habitats. The highest number of collected individuals occurred in the control shrubs, where 3 generalist ( $P$. collicola, $T$. rathkii, $A$. vulgare) and 2 forest specialist (T. ratzeburgii, O. planum) species were observed. In the removal shrubs, such species were presents, but their number was the lowest compared to control shrubs. In hay meadows, only 3 ( $P$. collicola, $T$. rathkii, $O$. planum) species were observed, and the relative high isopod abundance was resulted by the high number of $T$. rathkii. The most abundant isopod was the cosmopolitan A. vulgare, but it 
was absent in hay meadows. The abundance of this species was quite high in control shrubs compared to the other two habitats. The abundance of T. rathkii was also high in all habitat types. The relative abundance of $T$. rathkii was the highest on hay meadows. The relative abundance of the 2 forest specialist species was the highest in removal shrubs as compared to control shrubs, but the relative abundance of generalist species changed adversely. The differentiations of assemblages are represented in the ordinations as shown in Fig. 3.
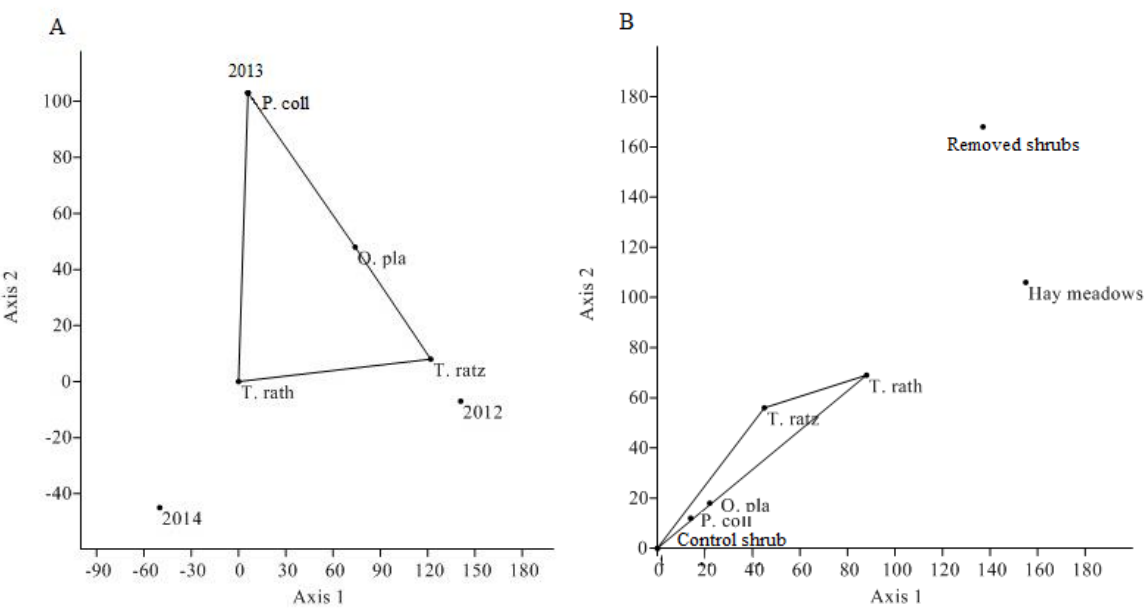

Figure 3. Annual (A) and regional (B) separation of isopod assemblages using Detrended Correspondence Analysis (see abbreviations of species in Table 2)

Grassland management can be considered as an intermediate disturbance [37], but it significantly changes the structure and composition of vegetation. It has positive effect on certain groups of arthropods [38, 39, 15, 39], but some animal taxa are affected negatively. For example, the high mortality of larvae, or pupae, of flower-visiting insects may be caused by mowing [40]. Grassland reconstruction treatments are composed of shrub removal followed by either mowing or grazing or burning [3]. Shrub removal can create changes in the vegetation structure of habitats in the short term, and it is followed by mowing, causing the changes in vegetation composition in the long term [10]. The alteration of habitats contributes to the changes in environmental factors, which affects food utilization, reproductive pattern [41], and the respiration of isopods. Isopods die in dry air because of the lack of $\mathrm{O}_{2}$, not desiccation [42].

We hypothesized that annual changes in vegetation structure caused by shrub removal will have negative effects on isopod diversity in the short term and the decreasing of diversity will continue in the long term. Our hypothesis was partly 
confirmed and partly not. On the one part, our hypothesis was not confirmed in that isopod diversity will decrease in the short term. Isopod species richness was relative to the ecological conditions of their habitats [43]. The created open habitats following shrub removal provided suitable conditions for more homogenizing species that tolerate the arid and warm environments. This is supported by the observed negative correlation between the annual changes in isopod diversity and number of individuals. Our results compare well to Davis and Sutton [44], where isopods' abundance was higher in semi-natural grasslands than woodlands. This is an unexpected result because isopods preferring decayed fallen litter [20] and shrub removal lead to the decreasing of structuration of habitats and the reducing of underwood. Similarly, according to Hassall [45], the simplification of habitat structure and less shelter sites affect the mortality of isopods. On the other part, our hypothesis was confirmed because isopod diversity and species richness decreased in the long term. There was no treatment in the second year (2013), and so a succession process started in the removal shrubs. Open habitats have a relatively high temperature; thus, they are characterized by low isopod diversity [46, 47]. At high environmental temperatures and positive photoreaction, isopods may leave their habitats [48] because humidity is a limiting key factor in their distribution [21]. Moreover, defoliation reduces the mass of leaf litter, which is an important food source for isopods [49]. Our results demonstrate well that the annual changes in vegetation structure have positively affected isopod diversity and species richness in the short term but not in the long term. Thermal tolerance of isopods is affected by their genetic constitution, ability of acclimatization, and the ambient humidity [42].

The examination of isopod diversity on a regional scale showed different results for annual dynamics. Our hypothesis was confirmed, according to which the highest isopod diversity would be in control shrubs and the lowest in hay meadow because of defoliation. Similarly, Moss and Hassal [50] showed that the isopod community was the most diverse if grassland management had not taken place. According to Paoletti and Hassal [17], isopod diversity decreases because of a combination of direct and indirect effects of management. Comparing the isopod abundance between hay meadows and removal shrubs, there were differences. We found higher isopod abundance in hay meadows formed during the long-term process. Similarly, Ilmarinen and Mikola [10] reported that mowing increased the number of bacterial feeder decomposers. Opposite to this, according to Sankaran and Augustine [51], defoliation can decrease the abundance and activity of soil decomposers in the long term. In removal shrubs formed during the short-term process, isopod abundance was lower compared to hay meadows. On the contrary, Fu and Cheng [52] showed that in the short term defoliation leads to the increasing of the abundance of soil decomposers because of release of carbon-rich 
compounds. Our results compare well to Grandchamp et al. [38], where species of open habitats were dominant on mown meadows.

\section{Conclusion}

Consequently, our survey did not find high isopod diversity and species richness in this Nature 2000 area, compared to other habitats, such as highway verges, where we found the highest species richness [53, 54]. In addition to reducing the diversity in the long term, changes in vegetation structure did not alter adequately the composition of isopod communities based on habitat preference. This study demonstrates that grassland managements are important in order to save habitats of several significant arthropod taxa, such as beetles or spiders, but it may not be important for other arthropod groups. Thus, the correct selection of target groups for interventions is worth considering. It is true that isopods are not important arthropods from a nature conservation point of view, but their contribution to ecosystem processes may be significant [55]. Therefore, it is necessary to study the ecology of isopods.

\section{Acknowledgements}

This work was part of the KEOP project. We thank the employees of the Bükk National Park Directorate, especially Gábor Magos, László Urbán, György Dudás, and Attila Kemény.

\section{References}

[1] Watkinson, A. R., Ormerod, S. J. (2001), Grasslands, grazing and biodiversity: editors' introduction, J. Appl. Ecol. 38(29), 233-237.

[2] Wamelink, W. (2007), Simulation of vegetation dynamics as affected by nitrogen deposition. $\mathrm{PhD}$ thesis. Wageningen University, Wageningen 3.

[3] Kelemen, J. (1997), Irányelvek a füves területek természetvédelmi szempontú kezeléséhez (Guidelines to the nature conservation managements of grassy habitats). Budapest. Természetbúvár Alapítvány Kiadó, 30-50.

[4] Wallis DeVries, M. F., Poschlod, P., Willems, J. H. (2002), Challenges for the conservation of calcareous grasslands in Northwestern Europe: integrating the requirements of flora and fauna. Biol. Conserv. 104, 265-273.

[5] Maret, M. P., Wilson, M. V. (2000), Fire and seedling population dynamics in western Oregon prairies. J. Veg. Sci. 11(2), 307-314.

[6] Poschlod, P., Karlık, P., Baumann, A., Wiedmann, B. (2008). The history of dry calcareous grasslands near Kallmunz (Bavaria) reconstructed by the application of palaeoecological, historical and recent-ecological methods. In: Szabó, P., Hédl, R. (eds.), Human nature: studies 
in historical ecology and environmental history. Institute of Botany of the Czech Academy of Sciences, Brno, CZ, 130-143.

[7] Mikola, J., Setälä, H., Virkajärvi, P., Saarijärvi, K., Ilmarinen, K., Voigt, W., Vestberg, M. (2009), Defoliation and patchy nutrient return drive grazing effects on plant and soil properties in a dairy cow pasture. Ecol. Monogr. 79, 221-224.

[8] Sørrensen, L. I., Kytöviita, M.-M., Olofsson, J., Mikola, J. (2008), Soil feedback on plant growth in a sub-arctic grassland as a result of repeated defoliation. Soil Biol. Biochem. 40, 2891-2897.

[9] Turgeon, A. J. (1999), Turfgrass management. $5^{\text {th }}$ edition. Prentice Hall, Upper Saddle River, NJ.

[10] Ilmarinen, K., Mikola, J. (2009), Soil feedback does not explain mowing effects on vegetation structure in a seminatural grassland. Acta Oecol. 35(6), 838-848.

[11] Noordijk, J., Delille, K., Schaffers, A. P., Sykora, K. V. (2009), Optimizing grassland management for flower-visiting insects in roadside verges. Biol. Conserv. 142(10), 2097-2103.

[12] Pozzi, S., Gonseth, Y., Hanggi, A. (1998), Evaluation of dry grassland management on the Swiss occidental plateau using spider communities (Arachnida: Araneae). Rev. Suisse Zool. 105(3), 465-485.

[13] Noordijk, J., Schaffers, A. P., Heijermanb, T., Boerc, P., Gleichmana, M., Sykora, K. V. (2010), Effects of vegetation management by mowing on ground-dwelling arthropods. Ecol. Eng. 36(5), 740-750.

[14] Malumbres-Olarte, A., Vink, C. J., Ross, J. G., Ruickshank, R. H., Paterson, A. M. (2013), The role of habitat complexity on spider communities in native alpine grasslands of New Zealand. Insect Conserv. Divers. 6, 124-134.

[15] Szmatona-Túri, T., Vona-Túri, D., Magos, G. and Urbán, L. (2017a), The effect of grassland management on diversity and composition of ground-welling spider assemblages in the Mátra Landscape Protection Area of Hungary. Biologia 72(6), 642-651.

[16] Mazalová, M., Šipoš, J., Rada, S., Kašak, J., Šarapatka, B., Kuras, T. (2015). Responses of grassland arthropods to various biodiversity-friendly management practices: is there a compromise? Eur. J. Entomol. 112, 734-746.

[17] Paoletti, M. G., Hassall, M. (1999), Woodlice (Isopoda: Oniscidea): their potential for assessing sustainability and use as bioindicators. Agric. Ecosyst. Environ. 74, 157-165.

[18] Abd el-wakeil, K. F. (2015), Effects of terrestrial isopods (Crustacea: Oniscidea) on leaf litter decomposition processes. J. Basic. Appl. Biol. 69, 10-16.

[19] Tuf, I. H., Tufová, J. (2005), Communities of terrestrial isopods (Crustacea: Isopoda: Oniscidea) in epigeon of oak-hornbeam forests of SW Slovakia. Ekológia 24, 113-123.

[20] Hassall, M. P., Turner, T. G., Rands, M. R. W. (1987), Effects of terrestrial isopods on the decomposition of woodland leaf litter. Oecologia 72, 597-604.

[21] Hornung, E. (2011), Evolutionary adaptation of oniscidean isopods to terrestrial life: structure, physiology and behavior. Terr. Arthropod. Rev. 4, 95-130.

[22] Warburg, M. R. (1965), Water relation and internal body temperature of isopods from mesic and xeric habitats. Physiol. Zool. 38, 99-109.

[23] Beron, P. (1997), On the high mountain Isopoda Oniscidea in the Old World. Hist. Nat. Bulgarica 8, 85-100.

[24] Wieser, W. (1966), Copper and the role of isopods in degradation of organic matter. Science 153 (3731), 67-69.

[25] Wieser, W. (1968), Aspects of nutrition and the metabolism of copper in isopods. Am. Zool. 8, 495-506.

[26] Wieser, W., Oberhauser, C. (1984), Ammonia production and oxygen consumption during the life cycle of Porcellio scaber (Isopoda, Crustacea). Pedobiologia 26, 415-419. 
[27] Davis, R. C. (1984), Effects of weather and habitat structure on the population dynamics of isopods in a dune grassland. Oikos 42(3), 387-395.

[28] Hammer, O., Harper, D. A. T., Ryan, P. D. (2001), PAST: Paleontological Statistics software package for education and data analysis. Palaeontologia Electronica 4(1).

[29] Nagendra, H. (2002), Opposite trends in response for the Shannon and Simpson indices of landscape diversity. Appl. Geogr. 22, 175-186.

[30] Hill, T. C. J., Walsh, K. A., Harris, J. A., Moffett, B. F. (2003), Using ecological diversity measures with bacterial communities. FEMS Microbiol. Ecol. 43, 1-11.

[31] Magurran, A. E. (2003), Measuring biological diversity, Oxford, Blackwell Publishing.

[32] Schmera, D., Erős, T. (2008), A mintavételi erőfeszítés hatása a mintareprezentativitásra. Acta Biol. Debrecina. Supplementum oecologica hungarica 18, 209-213.

[33] Hopkin, S. P. (1991), A key to the woodlice of Britain and Ireland (AIDGAP). Field Studies 7 , 599-650.

[34] Schmidt, C. (1997), Revision of the European species of the genus Trachelipus Budde-Lund, 1908 (Crustacea: Isopoda: Oniscidea). Zool. J. Linn. Soc. 121, 129-244.

[35] Farkas, S., Vilisics, F. (2013), Magyarország szárazföldi ászkarák faunájának határozója (Isopoda: Oniscidea), Nat. Somogy. 23, 89-124.

[36] Schmalfuss, H. (2003), World catalog of terrestrial isopods (Isopoda: Oniscidea): Stuttgarter Beitr. Naturk. Ser. A 654, 341.

[37] Connell, J. H. (1978), Diversity of tropical rainforests and coral reefs. Science 199(4335), 1304-1310.

[38] Grandchamp, A., Bergamini, A., Stofer, S., Niemela, J., Duelli, P., Scheidegger, C. (2005), The influence of grassland management on ground beetles (Carabidae, Coleoptera) in Swiss montane meadows. Agric. Ecosyst. Environ. 110(3-4), 307-317.

[39] Szmatona-Túri, T., Vona-Túri, D., Urbán, L., Magos, G. (2017b), The effect of grazing intensity on ground-dwelling spider of grassy and shrubby habitats. Acta Zoologica Bulgarica. In press.

[40] Johst, K., Dreschler, M., Thomas, J., Settele, J. (2006), Influence of mowing on the persistence of two endangered large blue butterfly species. Journal of Applied Ecology 43, 333-342.

[41] Warburg, M. R., Linsenmair, K. E., Bercovitz, K. (1984), The effect of climate on the distribution and abundance of isopods. In: Sutton, S. L., Holdich, D. M. (eds.), The biology of terrestrial isopods. The Zoological Society of London, Clarendon Press, Oxford, 339-367.

[42] Edney, E. B. (1968), Transition from water to land in isopod crustaceans. Am. Zool. 8, 309326.

[43] Herold, W. (1930), Beitragezur Verbreitung und Okologie der Landisopoden des Ostbalticums. Z. Morphol. Okol. Tiere. 18, 474-535.

[44] Davis, R. C., Sutton, S. L. (1978), A comparative study of changes in biomass of isopods inhabiting dune grassland. Sci. Proc. R. Dublin. Soc. 6, 223-233.

[45] Hassall, M. (1996), Spatial variation in favorability of a grass heath as a habitat for woodlice (Isopoda: Oniscidea). Pedobiologia 40, 514-528.

[46] Hornung, E., Warburg, M. R. (1995a), Seasonal changes in the distribution and abundance of isopod species in different habitats within the Mediterranean region of northern Israel. Acta Oecol. International Journal of Ecology 16(4), 431-445.

[47] Hornun, E., Warburg, M. R. (1995b), Isopod distribution at different scaling levels. Crustacean 9, 83-95.

[48] Bliss, D. E., Mantel, L. H. (1968), Adaptations of crustaceans to land: a summary and analysis of new findings. Am. Zool. 8, 673-685.

[49] Souty-Grosset, C., Badenhausser, I., Reynolds, J. D., Morel, A. (2005), Investigations on the potential of woodlice as bioindicators of grassland habitat quality. Europ. J. Soil Biol. 41, $109-116$. 
[50] Moss, A., Hassal, M. (2006), Effects of disturbance on the biodiversity and abundance of isopods in temperate grasslands. Europ. J. Soil Biol. 42(1), 254-268.

[51] Sankaran, M., Augustine, D. J. (2004), Large herbivores suppress decomposer abundance in a semiarid grazing ecosystem. Ecology 85, 1052-1061.

[52] Fu, S., Cheng, W. (2004), Defoliation affects rhizosphere respiration and rhizosphere priming effect on decomposition of soil organic matter under a sunflower species: Helianthus annuus. Plant and Soil 263, 345-352.

[53] Vona-Túri, D., Szmatona-Túri, T., Kiss, B. (2013), Szárazföldi ászkarák együttesek (Crustacea: Isopoda: Oniscidea) a Magyarországi autópályák szegélyzónájában. Termvéd. Közl. 19, 106116.

[54] Vona-Túri, D., Szmatona-Túri, T., Kiss B. (2015), Autópályák ászkarák-közösségeinek (Crustacea: Isopoda: Oniscidea) ökológiai vizsgálata. Termvéd. Közl. 21, 395-406.

[55] Zimmer, M. (2002), Nutrition in terrestrial isopods (Isopoda: Oniscidea): an evolutionaryecological approach. Biol. Rev. 77, 455-493. 